\title{
ELECTRON MICROSCOPIC STUDIES OF THE ROOT NODULE OF PTEROCARPUS INDICUS
}

\author{
SHIRO HIGASHI, MIKIKO ABE, GLORIA D. REYES,* \\ AND IRENEO J. MANGUIAT* \\ Department of Biology, Faculty of Science, Kagoshima University, \\ Kagoshima 890, Japan \\ * BIOTECH, University of the Philippines at Los Baños, \\ Coliege, Laguna, Philippines
}

(Received February 25, 1987)

The morphology of the root nodules of Pterocarpus indicus Willd ("narra") was studied by scanning and transmission electron microscopy and by light microscopy. The electron micrographs revealed that the nodule tissue cells gradually change from large to small size from the epidermal tissue to the inner core tissue. The epidermal cells have hard and thick cell walls surrounded by cork. The inner core cells have very thin cell walls (about $0.3 \mu \mathrm{m}$ thick). The inner core cells contain numerous bacteroids $(1-1.5 \times 2-4.5 \mu \mathrm{m}$ in size $)$.

Pterocarpus belongs to the family Leguminosae which includes four species, $P$. indicus, $P$. vidalianus, $P$. pubescens, and P. blancoi. Pterocarpus indicus Willd is locally known as "narra" in the Philippines and is the country's national tree. In its native ecological conditions, the trees grow big and tall, usually reaching $100 \mathrm{~cm}$ in diameter and 20 to $30 \mathrm{~m}$ high. Narra bears profuse and attractive golden flowers. The lumber of narra is commercially important. It is used for high priced furniture, panelling, and high quality construction materials ( 1 ).

Fundamental studies of the nitrogen-fixing bacteria are important in the tropical zone because the leaching of nitrogen from the soil by heavy rains is a serious problem. The infection and nodulation of the leguminous trees and their symbiont have not been properly studied because the root tissues have very hard and thick cell walls. Moreover, physiological studies of the root nodule development of this leguminous trees have not been established yet. As a consequence, analytical techniques used for studying the infection process in other leguminous plants cannot be applied. Many difficulties exist concerning the fine structural

Address reprint requests to: Dr. Higashi, Department of Biology, Faculty of Science, Kagoshima University, Kagoshima 890, Japan. 
analysis of the "narra" nodules by electron microscopy. For example, it is necessary to establish effective ways to prepare the tissues for electron microscopic specimens, such as the resin permeation method.

This paper reports on scanning and transmission electron microscopic studies of "narra" nodules and describes their fine structures.

\section{MATERIALS AND METHODS}

Plant material. Root nodules were obtained from a young seedling of Pterocarpus indicus from Los Baños, Laguna, Philippines. The seedling was about 4 months old and 2 feet high.

Electron microscopy. The specimens were fixed for scanning electron microscopy, dehydrated, and treated for viewing as previously outlined(2). For transmission electron microscopy, the nodule specimens were fixed for $3 \mathrm{hr}$ at $22^{\circ} \mathrm{C}$ using $2.5 \%$ glutaraldehyde in $0.05 \mathrm{~m}$ cacodylate buffer $(\mathrm{pH} 6.8)$. They were post-fixed with $1 \%$ buffered osmium tetroxide $\left(\mathrm{OsO}_{4}\right)$ for another $3 \mathrm{hr}$ at the same temperature. The nodules were then dehydrated through an alcohol series and placed in glycidyl $n$ butyl ether and embedded in Spurr-resin(3). Thin sections were obtained with an ultra microtome. The sections were stained in two solutions following REYNOLDS' staining method (4): $2 \%$ uranyl acetate in double-distilled water for $4 \mathrm{hr}$, and $80 \mathrm{~mm}$ lead nitrate for $4 \mathrm{~min}$.

For light microscopy, thick sections cut with a microtome were embedded in resin. The sections were stained with $0.05 \%$ toluidine blue in $0.1 \mathrm{M}$ phosphate buffer (pH 7.0) for $2 \mathrm{hr}$.

The specimens were observed under a scanning electron microscope (Hitachi S-450, Japan) operating at $20 \mathrm{kV}$ and under a transmission electron microscope (Hitachi H-600S, Japan) at $100 \mathrm{kV}$.

\section{RESULTS AND DISCUSSION}

A scanning electron micrograph of the longitudinal section of a "narra" nodule (Fig. 1) revealed that it consists of four kinds of tissue, i.e., inner-core cells which contain bacteroids (bd), epidermal cells or the outermost layer cells (ep), parenchyma cells (pa), and dividing-zone cells (se). The inner core cells are separated from the parenchyma cells by the dividing zone. The cells of the outer layer have thick cell walls surrounded by hard cork. This made the preparation of specimens for electron microscopic examination very difficult.

The inner-core cells have thinner walls than the cells in the outer layers. They are globular in form (Figs. 2 and 3). Generally, the mature infected-cells are $4 \times$ to $8 \times$ the volume of those that are bacteria-free (5). For example, the average sizes of bacteroid-containing cells of peas, clovers, and bens are ca. 120, 50, and $70 \mu \mathrm{m}$ in diameter respectively. However, the bacteroid-containing cells of "narra" are small (ca. $25 \mu \mathrm{m}$ ). This is considered to be a peculiar nodule morphology be- 


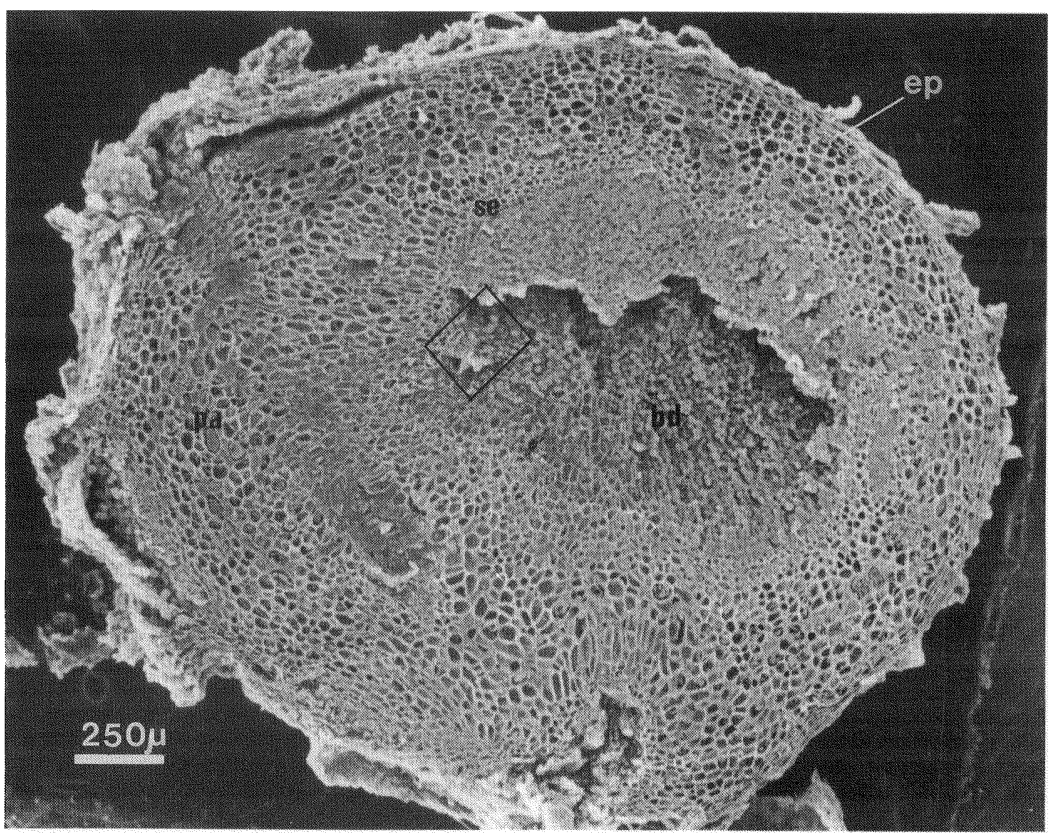

Fig. 1. Scanning electron micrograph of a longitudinal section of a "narra" nodule. ep, epidermal cells; pa, parenchyma cells; se, dividing-zone cells; bd, bacteroid-containing cells.

cause the cell size of the nodule tissue gradually decreases from the outermost layer to the inner core (Fig. 1).

Figure 4 shows three different cell types as viewed under a light microscope: core cells which contain the bacteroids (bd), middle layer or dividing-zone cells (se), and parenchyma cells (pa) containing vascular bundles (vb). It seems that the meristematic cells of this nodule exist around the front zone of the core tissue (in vicinity of the area indicated by "se").

The bacteroids $(1-1.5 \times 2-4.5 \mu \mathrm{m}$ in size) are packed in the core cells and contain a few intracellular granules which are electron-transparent (indicated by small arrows in Fig. 5a and b). Presumably, these are poly- $\beta$-hydroxybutyrate granules $(6,7)$ which have accumulated inside the bacteroid cells. Several bacteroid cells were observed in a group surrounded by a peribacteroidal membrane, indicated by the large arrow in Fig. 5b. The nodule bacteroid belongs to the plural type in the morphological classification of the nodule $(8,9)$. Seen by transmission electron microscopy, the core cells have an unusual form of cell wall, consisting of very thin cell wall regions (Fig. 5a and b). They are about $0.3 \mu \mathrm{m}$ in thickness. The function of these unusual cell-wall regions is not known; however, it is presumed that they play a role in interactions between cells.

Though a large number of infection threads are observed in a nodule tissue of 


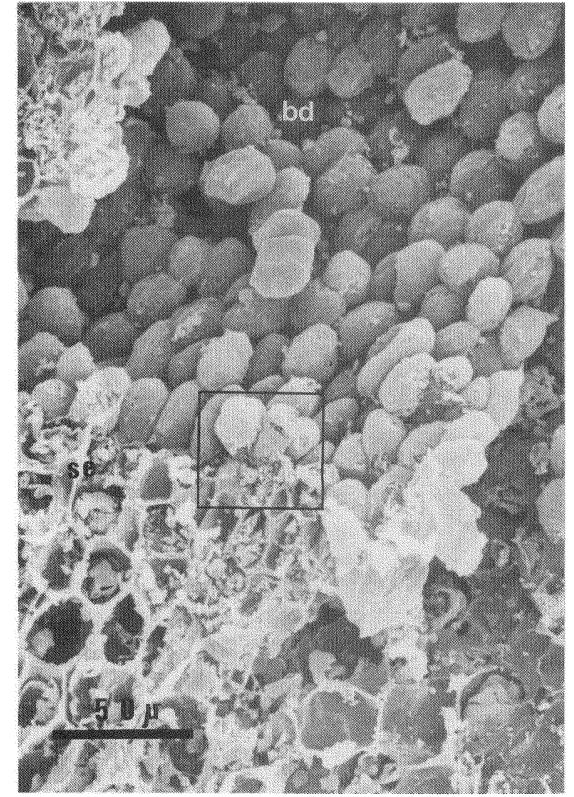

Fig. 2. Enlarged inner core tissue representing the area enclosed by a square in Fig. 1. se, dividing-zone cells; bd, bacteroid-containing cells.

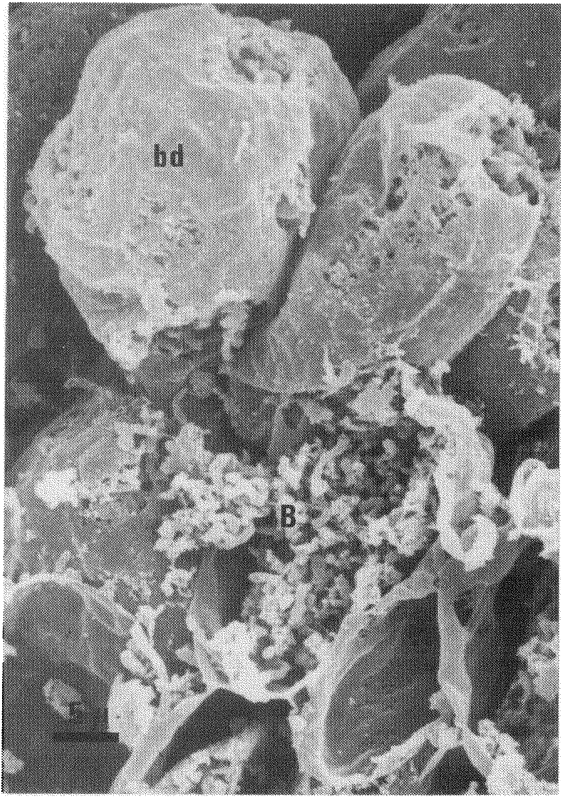

Fig. 3. Enlarged scanning electron micrograph of the area enclosed by a square in Fig. 2. bd, bacteroid-containing cells; B, bacteroids.

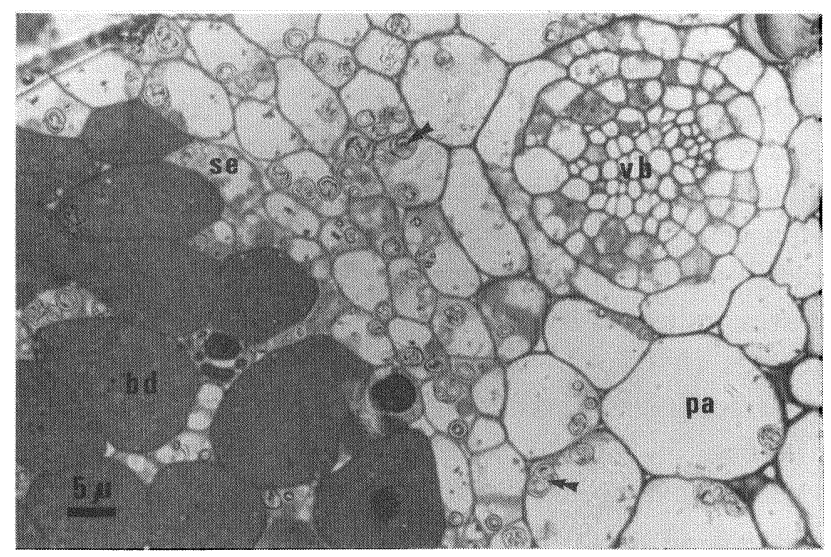

Fig. 4. A light micrograph showing four kinds of tissue of the "narra" nodule. vb, vascular bundle; pa, parenchyma cells; se, dividing-zone cells; bd, bacteroid-containing cells; double arrows, amyloplasts.

common legumes (10), no infection threads were detected in these nodules. The primary evidence for the infection by "narra" rhizobia and their characteristics need to be investigated further. So in the analysis of the infection process on the root 


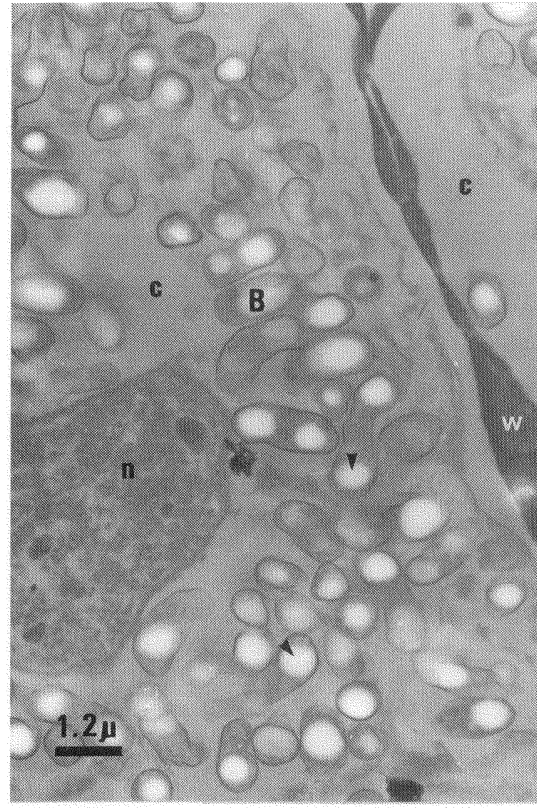

a

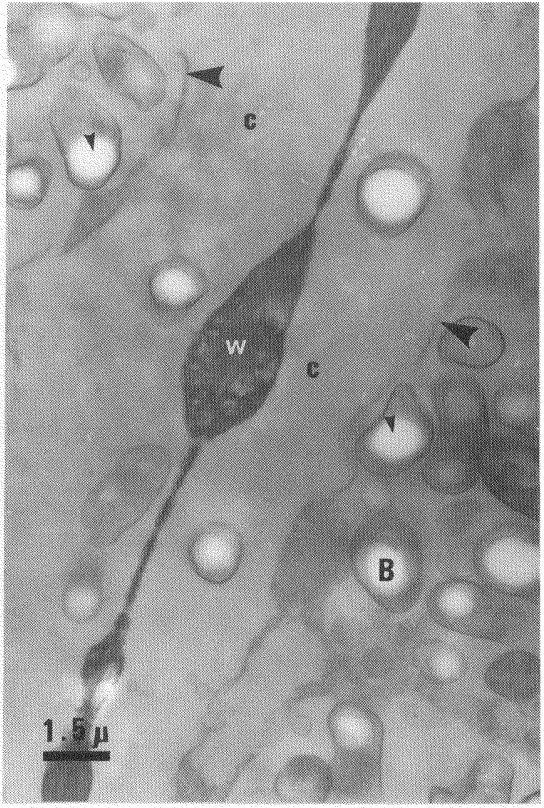

b

Fig. 5a and b. Transmission electron micrographs of bacteroid-containing cells. c, cytoplasm of nodule cell; $\mathrm{w}$, cell wall of nodule cell; $\mathrm{B}$, bacteroid; small arrows, poly- $\beta$ hydroxybutyrate granules; large arrow, peribacteroidal membrane.

nodule bacteria, we need to develop apparatus and techniques for culturing woody legume seedlings under sterile conditions.

\section{REFERENCES}

1) N. P. Lansigan, "Narra": The National Tree of the Philippines, Metro Manila: Tree Preservation Foundation of the Philippines (1980), p. 1.

2) S. Higashi and M. Abe, Appl. Environ. Microbiol., 40, 1094 (1980).

3) A. R. SpurR, J. Ultrastruct. Res., 12, 31 (1969).

4) E. S. Reynolds, J. Cell Biol., 19, 138 (1963).

5) J. M. VinCENT, In The Biology of Nitrogen Fixation, ed. by A. QuisPel, North-Holland/American Elsevier, Amsterdam, Oxford, and New York (1974), p. 272.

6) B. Bassett, R. N. Goodman, and A. Novacky, Can. J. Microbiol., 23, 573 (1977).

7) R. W. Ridge and B. G. Rolfe, Appl. Environ. Microbiol., 50, 717 (1985).

8) A. K. Bal, S. Shantharam, and D. P. S. Verma, Can. J. Microbiol., 20, 1096 (1980).

9) D. A. Callaham and J. G. Torrey, Can. J. Bot., 59, 1674 (1981).

10) S. Higashi, K. Kushiyama, and M. Abe, Can. J. Microbiol., 12, 947 (1986). 